\title{
"Halal" Sex Tourism from Feminism Prespective
}

\author{
E Kusumawardhani \\ Universitas Padjadjaran, Bandung \\ elisa19001@mail.unpad.ac.id
}

\begin{abstract}
This research discuss about "halal" sex tourism or marriage with an agreement in Bogor, West Java, Indonesia. Bogor as one of the favorite tourism city in Indonesia by domestic or foreign tourists. One interesting tour in Bogor is "halal" sex tourism conducted by foreign tourists obtained from the Middle East. It is happened because there is a demand of Middle East tourist and the lack of education and economic problems of woman. The condition creates Halal Tourism which is married with an agreement. The impacts of "halal" sex tourism are violence to women in marriage and if any children are born in marriage with this agreement, the children do not have born certificate because their parents don't have legal document. Therefore the research wants to know more clearly about "halal" sex tourism that occurs in Bogor from feminism prespective. This research uses qualitative methods and data collection that is obtained through literature study with feminism theory to explain the reason why woman always be object and victims especially in this phenomenon. The results of this study indicate that "halal" sex tourism happened in Bogor which is specially in Kampung Arab, Puncak area, Cisarua. Women work as "wife" with an agreement but they are treated as commercial sex workers who get violence in their contract marriage and another disadvantage things. But the local government does not yet have a significant role in resolving the issue of "halal" sex tourism.
\end{abstract}

Keywords: "Halal" sex tourism, feminism, woman

\section{INTRODUCTION}

Tourism is a social phenomenon which also encompasses cultural and economic phenomena. This phenomenon allows the movement of people to a country or place outside their environment for personal or work purposes. In the last few decades, the tourism industry has experienced sustainable growth. This can be seen from the data for six consecutive years, according to the World Travel \& Tourism Council, the tourism industry has surpassed global economic growth. In addition, the tourism industry has also surpassed other important economic sectors such as oil exports, food and car production [1]. Thus, the tourism industry becomes interesting to be discussed seen from some of the phenomena therein.

\footnotetext{
${ }^{1}$ In this study, Halal words do not mean like the real meaning of the word. In this research, halal should look like real halal, but it means illegal. That is why the writer uses punctuation (" ") in every halal word in this study.
} 
In Indonesia, there are several regions that are favorite destinations for local visitors and international tourists. One of those is the Puncak area located in Bogor. The peak itself is located between Bogor Regency and close to Jakarta as the capital city of Indonesia. The location of the city of Bogor between the routes to Puncak or Cianjur as well as easy access to roads and transportation to Bogor from Jakarta makes Bogor a favorite destination by international tourists. This can be seen from the increase of foreign tourist arrivals in Bogor in 2012-2016.

Table 1. Data on International Tourist Visits of Bogor City in 2012-2016

\begin{tabular}{|c|c|}
\hline Year & International Tourist \\
\hline $\mathbf{2 0 1 2}$ & 110.975 \\
\hline $\mathbf{2 0 1 3}$ & 104.780 \\
\hline $\mathbf{2 0 1 4}$ & 220.981 \\
\hline $\mathbf{2 0 1 5}$ & 202.108 \\
\hline $\mathbf{2 0 1 6}$ & 244.646 \\
\hline
\end{tabular}

Source: Bogor City Culture and Tourism Office in 2012-2016 [2]

However, the development of massive tourism also has a negative effect. This negative effect is formed by the chance of losing local cultural values and the local population is affected by foreign cultures without filtering out its essence [3]. This can be seen from the presence of Arab villages in the peak area of Bogor as a result of the large number of tourists from the Middle East to Bogor. Unfortunately their presence has a negative impact on the surrounding population. The negative impact of this is the emergence of a type of tourism referred to as "halal" sex tourism in Bogor which results in contract marriages. So the question arises as to whether "halal" sex tourism is part of human trafficking. Therefore, this study was conducted to explain "halal" sex tourism as a negative phenomenon that arises in the development of tourism and part of an oppression of woman.

In addition, this research is also expected to provide new knowledge to the public about the phenomenon of "halal" sex tourism and provide knowledge in order to reduce so as to eliminate phenomenon like this that make woman and children victims of sexual oppression. This research was conducted because there is no research that explains the case of "halal" sex tourism from feminism prespective. Previous research has examined to find out and try to understand the motivation of women who want to do contract marriage with tourists from the Middle East [4]. Research by Siti Sarah Maripah that describes in a comprehensive way how the phenomenon of contract marriage in the Village of South Tugu, Cisarua District, Bogor Regency [5]. Subsequent research discusses the same thing, but in terms of Islamic religious law, where contract marriages that occur are haram [6]. Research by Nurlailiyah Aidatussholihah links contract marriages that occur to facts, Islamic law and positive laws that apply in Indonesia and shows marriages that occur illegally [7]. Other studies explain the reasons for Middle Eastern tourists to choose Bogor as a tourist destination until the steps of contract marriage occur [8]. These studies show that there is a powerlessness of woman so that this phenomenon can occur.

\section{RESEARCH METHOD}

In this study using descriptive qualitative research methods, to explain "halal" sex tourism in Bogor from feminism prespective. Data analysis method used is literature study. The data collection techniques and tools used in this research are documentation studies. 
Documentation studies are data collection techniques that do not directly addressed to research subjects [9]. Therefore, the concepts used in this study is feminism.

To analyze, writer used feminism concepts in this research. Feminism is a movement by women who demand equal rights and justice with men. This is based on the rights relating to basic human rights written in the Declaration of Human Rights 1948.

\section{RESULTS AND DISCUSSION}

To analyze, writer used two concepts in this research. There are human security and "halal" sex tourism. On the issue of international security, the subject is no longer only about the security of a country but has also reached the stage of human security. Human trafficking is an extension of traditional security studies to non-traditional security studies. Its understanding has been discussed in international forums and has become an issue of global problems. The United Nations (UN) has also formed a special work unit to tackle human trafficking. United Nations on Drugs and Crime (UNODC) is an institution under the auspices of the United Nations specifically to deal with human trafficking and smuggling illegal immigrants. According to UNDOC, the definition of human trafficking is income (business) that is obtained by evil means, such as coercion, fraud or deception with the aim of exploiting them [10].

Another understanding was also expressed by M Gandhi Lapian \& Geru. A Hetty through the UN protocol that defines human trafficking as an activity to seek, send, move, accommodate or accept workers with threats, violence or other forms of coercion in the form of kidnapping, deceiving, coaxing victims, abusing power or authority or exploiting disobedience, curiosity, powerlessness and lack of protection for victims or by giving or receiving payment or payment in order to obtain permission or approval from parents, guardians, or other people who have authority over the victim with a view to extorting power (exploiting victims) [10].

Other explanations of definitions of human trafficking have also expanded. This is as explained by Wijers and Lap-Chew that human trafficking is a movement of people, especially women and children with and or without the consent of those concerned in a country or abroad with the aim of all forms of exploitative labor, not only concerning prostitution and servitude under the guise of marriage (servile marriage) [11].

Interpol as an inter-governmental organization (IGO) also categorizes human trafficking into four groups. Among them there is trafficking of women for the purpose of sexual exploitation where women are tempted by offers of better and more promising jobs but in fact they are exploited in sexual slavery and commercial sexual exploitation of children in the tourism industry [12].

"Halal" sex tourism is one type of sex tourism in Indonesia. However, "halal" sex tourism takes the form of contract or temporary marriage and considers it is legal in the eyes of the state or legal law in religious law. In fact, in Islamic religious law, this temporary marriage or commonly called mut'a marriage is illegal or illegitimate. Majelis Ulama Indonesia (MUI) as the highest institution in regulating Islamic religious law in Indonesia has issued a fatwa on this matter. MUI fatwa states that mut'ah marriage or contract marriage has an illegal law. This means that temporary marriage or mut'ah is forbidden to be performed or prohibited in Islam. The perpetrators of this temporary marriage are usually foreign tourists and local women who are adults or who are still under age or children [13].

The main reason why this temporary marriage can occur is due to the pleasure of the bridegroom or it can be said to fulfill their sexual satisfaction in a lawful manner, namely by marriage even though it is only temporary or there is a contract in it. In addition, the reasons behind some brides wanting to have contract marriages are economic incapacity, improving 
offspring and lack of religious education or free sex education or the effect of their temporary marriages [13]. Three factors that cause human trafficking are the poverty, the weak control and oversight of government, also the transactional crime and globalization [10].

Cisarua region is a favorite area for illegal immigrants who usually come from Iran, Afghanistan, Iraq, Sri Lanka and Rohingya. The number of illegal immigrants, estimated at around 600 people, has settled approximately from 2008 to 2013 . However, they are not people who are lacking in economic terms. This is because these illegal immigrants are able to rent a house or even a hotel room for a long time. This phenomenon has received support from local residents who feel benefited by the presence of these illegal immigrants [14].

"Halal" sex tourism that has been involved in contract marriages has become the concern of various parties including the Ministry of Religion. Balitbang research results of the Ministry of Religion, specifically there are two types of contract marriages. The first type of contract marriage is the actual and official contract marriage. On this type, the male contact the agent directly to meet a woman's family to propose and marry the woman. They will be married by local religious leader with an official marriage procession and witnesses and their guardians can also be accounted for his testimony. The second type of contract marriage is a deviant type. Where in this type of marriage contract, has led to hidden prostitution. This is because local religious leaders are not willing to lead the wedding procession, wedding processions are held in makeshift places such as in restaurants or villas, marriage registries, witnesses and guardians of marriage are fake. Even the woman as the bride and groom are available at some boarding houses. Usually these women come from Cianjur and Subang at a rate of Rp. 5 million to Rp. 20 million which is the livelihood for these women [15].

The phenomenon of contract marriage has existed since 28 years ago. This phenomenon is familiar in Middle Eastern countries where women who contract marriages are usually forced to do it again for economic reasons. Contract marriages or commonly known as mut'a marriage are marriage that are conducted within a certain period and end in accordance with an agreement agreed by both parties. According to the term, the general understanding of the definition of mut'ah by the scholars is a contract undertaken by a man to marry a woman within a period of day, week or month or who has been determined (agreed) such as a month, two months, one day, two days ago the woman will be left after the agreed period ends [5].

"Halal" sex tourism is usually carried out by tourists from the Middle East who are on holiday to Indonesia, especially crowded in July to September. In fact they have a special term for the Puncak Bogor area, named jabal [15]. The process of contract marriage which eventually gave birth to halal sex tourism did indeed only involve two witnesses, a headman, a stamped agreement and a dowry of course. The women who are going to be married by Arab tourists are usually provided by the pimps for the contract marriage services. The dowry obtained by the woman through contract marriage will be halved with the pimp who distributes it to Middle Eastern tourists. But in addition to looking for a vacation and sexual satisfaction in a "halal" way, the motivation of the perpetrators, especially Middle Eastern tourists who want to have a contract marriage turned out to have other reasons in practice. They deliberately enter into a contract marriage to avoid the Raids and raids carried out by the security forces in this case the police and immigration officers [16].

Based on an explanation of the previous definition of human trafficking, "halal" sex tourism includes human trafficking. Where there is a process of helplessness of the victim in economic terms that receives rewards for exploiting victims in this case sexual exploitation. Women who get married in contract marriages do so because of economic demands. Either they are married women and their husbands have given up their wives to perform contract marriage with foreign tourists from the Middle East [16] or these women are indeed single women who 
have to worked to provide for their economies as the backbone of their family since young. In fact, she has been in the profession of contract marriage for 11 times from the age of 17 to 18 years [17]. Even in some cases of contract marriages, the women involved are still children. They are not even involved in contract marriages because their parents did it [18].

In a contract marriage there is also no specific obligation that must be carried out by the contract wife in addition to serving the sexual needs of the contract husband until he is satisfied. The contract husbands who are tourists only pay a sum of money or what they call dowry at the beginning but do not fulfill obligations like husbands in general such as giving spending money [5]. Contractual marriage will also lead to sexual violence [19].

\section{CONCLUSIONS}

"Halal" sex tourism that occurs in the area of Cisarua, Bogor Regency is a contractual marriage which is a social phenomenon that arises due to the swift flow of tourism and globalization. Contract marriages that occur are part of human trafficking due to economic powerlessness and knowledge of the victim. The violence experienced, sexual exploitation to the unclear status of children which result in the child is not being able to denounce formal education in school became a long-term negative effect experienced by contract marriages, especially Indonesian women who were married by foreign tourists from the Middle East. This is the task of the Government which is indeed very difficult to trace the contract marriage itself.

\section{REFERENCES}

[1] UNWTO, "International Tourism Highlights International tourism continues to outpace the global economy," pp. 1-24, 2019.

[2] C. HANDAYANI, "ANALISIS POTENSI DAN PRIORITAS PENGEMBANGAN PARIWISATA DI KOTA BOGOR PROVINSI JAWA BARAT," Universitas Muhammadiyah Surakarta, 2018.

[3] M. M. Z., "Potensi wisata kabupaten bogor," Bandung, 2011.

[4] U. Suhud and N. S. Sya 'bani, "Halal Sex Tourism in Indonesia:Understanding the Motivation of Young Female Host to Marry with Middle Eastern Male Tourists," Issn, vol. 5, no. 25, pp. 2222-1700, 2014.

[5] S. S. Maripah, "Fenomena Kawin Kontrak Di Kawasan Puncak Bogor," Sosietas, vol. 6, no. 2, 2016.

[6] Surahman, "Praktek nikah wisata di puncak desa tugu selatan kecamatan cisarua kabupaten bogor (jawa barat) di tinjau dari hukum islam," Universitas Islam Negeri Syarif Hidayatullah Jakarta, 2011.

[7] N. Aidatussholihah, "Antara Normatif, Yuridis dan Realita."

[8] P. Hijjang, M. Tang, and M. Farid, "The Tourist Contract Marriage In Cisarua SubDistrict Bogor Regency West Java," Int. J. Sci. Technol. Res., vol. 4, no. 2, pp. 142 144, 2015.

[9] D. I. Soehartono, METODE PENELITIAN SOSIAL: Suatu Teknik Penelitian Bidang Kesejahteraan Sosial dan Ilmu Sosial Lainnya. Bandung: PT. Remaja Rosdakarya Offset, 2011.

[10] B. Winarno, DINAMIKA ISU-ISU GLOBAL KONTEMPORER, 2014th ed. Yogyakarta: CAPS (Center of Academic Publishing Service), 2014.

[11] AMALIA SHOLICHAH, "PERDAGANGAN ORANG MENURUT UNDANGUNDANG NOMOR 21 TAHUN 2007 DAN MENURUT HUKUM ISLAM (Analisis 
Yuridis Sosiologis di Kabupaten Tulungagung)," INSTITUT AGAMA ISLAM NEGERI TULUNGAGUNG, 2012.

[12] J. Foo, "Cost Of Human Trafficking in Southeast Asia," 2013. [Online]. Available: http://www.vietstudies.info/kinhte/cost_of_human_trfficking.htm.

[13] L. Patrick, B. Eric, F. Francis, and P. Sarah, "Online sexual exploitation of children," Sex. Offending, pp. 237-256, 2018.

[14] Gagah, "Jejak Imigran Gelap di Cisarua, Budaya Kawin Kontrak dan Bocah Berhidung Bangir," detikNews, 2013. [Online]. Available: https://news.detik.com/berita/d2433451/jejak-imigran-gelap-di-cisarua-budaya-kawin-kontrak-dan-bocah-berhidungbangir. [Accessed: 15-Nov-2019].

[15] Y. A. (Editor), "Istilah Jabal dalam Fenomena Kawin Kontrak di Puncak, Tarifnya Rp 5 Juta sampai...," JawaPos.com, 06-Nov-2016. [Online]. Available: https://www.jawapos.com/jpg-today/06/11/2016/istilah-jabal-dalam-fenomena-kawinkontrak-di-puncak-tarifnya-rp-5-juta-sampai/. [Accessed: 15-Nov-2019].

[16] Andrall, "Soal Fenomena Kawin Kontrak pada 'Musim Arab', Bagaimana Menurutmu?," hipwee, 2017. [Online]. Available: https://www.hipwee.com/wedding/soal-fenomena-kawin-kontrak-pada-musim-arabbagaimana-menurutmu/. [Accessed: 18-Nov-2019].

[17] T. (editor) Malaka, "Pengakuan Remaja 18 Tahun Si Eneng Sudah 11 Kali Kawin Kontrak, Segini Mahar yang Diterima,” BANGKAPOS.com, 2018. [Online]. Available: https://bangka.tribunnews.com/2018/03/11/pengakuan-remaja-18-tahun-si-enengsudah-11-kali-kawin-kontrak-segini-mahar-yang-diterima?page=all. [Accessed: 18Nov-2019].

[18] N. Nashrullah, "Kawin Kontrak Marak, Prostitusi Terselubung? Ini Kata Pakar," REPUBLIKA.co.id, 2019. [Online]. Available: https://nasional.republika.co.id/berita/pt4y6g320/kawin-kontrak-marak-prostitusiterselubung-ini-kata-pakar. [Accessed: 18-Nov-2019].

[19] M. A. Fajar, "Fenomena Kawin Kontrak di Puncak: Sewa Tiga Hari Plus Vila, Bayar, Main, Selesai," JPNN.com, 16-Sep-2019. [Online]. Available: https://www.jpnn.com/news/fenomena-kawin-kontrak-di-puncak-sewa-tiga-hari-plusvila-bayar-main-selesai. [Accessed: 18-Nov-2019]. 